\title{
Pertimbangan Hakim Dalam Putusan Perkara Tindak Pidana Narkotika
}

\author{
Sri Dewi Rahayu, Yulia Monita \\ Fakultas Hukum, Universitas Jambi, Indonesia \\ Author's Email Correnspondence: dewirahayu190897@gmail.com
}

\begin{abstract}
ABSTRAK
Artikel ini bertujuan untuk menganalisis dasar pertimbangan hakim dalam penjatuhan pidana terhadap pelaku penyalahguna narkotika golongan I bagi diri sendiri. Metode penelitian ini menggunakan penelitian hukum Yuridis Normatif. Hasil dari penelitian ini menunjukkan bahwa penyebab hakim menjatuhkan putusan berbeda terhadap kedua kasus ini karena terdapat keadaan yang meringankan terhadap kedua terdakwa. Pada studi kasus keadaan yang meringankan yang dipertimbangkan oleh hakim yaitu: karena terdakwa merupakan korban penyalahguna narkotika yang sudah kecanduan serta didukung dengan keterangan saksi di persidangan. Oleh karena itu hakim harus mempertimbangkan fakta yuridis, fakta persidangan dan fakta sosiologis dari terdakwa. Hal ini dilakukan agar terdakwa merasa bahwa hakim menjatuhkan putusan pidana sesuai dengan perbuatan terdakwa.
\end{abstract}

Kata Kunci: Dasar

pertimbangan; putusan; tindak pidana narkotika

\section{ARTICLE HISTORY}

Submission: 13 December 2020

Accepted: 03 February 2020

Publish: 07 February 2020

KEYWORDS: Considerations of judgdes; verdict; narcotics offender

\begin{abstract}
This article aims to analyze the basic considerations of judges in convicting criminals against class I narcotics abusers themselves. This research method is a normative legal research. The results of this study indicate that the cause of the judge handed down a different verdict in these two cases because there were circumstances that alleviated the two defendants. In the case study the mitigating circumstances considered by the judge are: because the defendant is a victim of narcotics who are addicted and supported by witness testimony at the trial. Therefore the judge must consider the juridical facts, the facts of the trial and the sociological facts of the defendant. This was done so that the defendant felt that the judge handed down the criminal verdict according to the defendant's actions.
\end{abstract}

\section{A. Pendahuluan}

Narkotika merupakan zat atau obat yang sangat bermanfaat khususnya di dunia medis dan di perlukan untuk pengobatan penyakit tertentu. Namun jika di salahgunakan atau digunakan tidak sesuai dengan standar pengobatan dapat menimbulkan akibat yang sangat merugikan bagi perorangan atau masyarakat khususnya generasi muda. Hal ini akan lebih merugikan jika disertai dengan penyalahgunaan dan peredaran gelap Narkotika yang dapat mengakibatkan bahaya 
yang lebih besar bagi kehidupan dan nilai-nilai budaya bangsa yang pada akhirnya akan dapat melemahkan ketahanan Nasional. ${ }^{1}$

Pada Pasal 1 angka (1) Undang-Undang nomor 35 Tahun 2009 Tentang Narkotika menentukan bahwa yang dimaksud dengan narkotika adalah: Zat atau obat yang berasal dari tanaman maupun bukan tanaman baik sintetis maupun semi sintetis yang dapat menyebabkan penurunan atau perubahan kesadaran, hilangnya rasa, mengurangi sampai menghilangkan rasa nyeri, dan dapat menimbulkan ketergantungan yang dibedakan ke dalam golongan-golongan sebagaimana terlampir dalam undang-undang ini.

Penyalahgunaan dan peredaran gelap narkotika saat ini mengancam berbagai aspek kehidupan serta kelangsungan hidup bangsa dan Negara, karena pengguna narkotika tidak lagi didominasi oleh kalangan orang dewasa tetapi juga remaja dan anak-anak yang merupakan asset berharga bangsa. Jika hal ini tidak ditanggapi secara serius maka penyalahgunaan dan peredaran gelap narkotika akan terus meningkat.

Secara yuridis penggunaan narkotika hanya digunakan untuk tujuan pengembangan ilmu pengetahuan dan pelayanan kesehatan, namun dalam kenyataan pemakaiannya sering disalahgunakan. Penggunaan narkotika sudah dijadikan sebagai objek bisnis dan berdampak pada kegiatan merusak mental, baik fisik maupun psikis generasi muda. ${ }^{2}$ Kebijakan pemerintah di bidang kesehatan merupakan upaya untuk mewujudkan masyarakat Indonesia yang sejahtera, adil, dan makmur yang merata materil dan spiritual berdasarkan Pancasila dan Undang-Undang Dasar Negara Republik Indonesia Tahun 1945. Untuk meningkatkan derajat kesehatan, diperlukan peningkatan di bidang pengobatan dan pelayanan kesehatan dengan upaya mengusahakan ketersediaan narkotika jenis tertentu serta melakukan upaya pencegahan dan pemberantasan bahaya penyalahgunaan dan peredaran gelap narkotika dan prekursor Narkotika. ${ }^{3}$ Dalam hal ini, Pemerintah Indonesia telah bertekad bulat, bahwa terhadap penyalahgunaan dan peredaran gelap narkotika merupakan bahaya yang harus ditangani secara dini dengan melibatkan seluruh potensi yang ada, baik oleh Pemerintah, masyarakat, Lembaga Swadaya Masyarakat (LSM) dan pihak-pihak yang terkait. ${ }^{4}$

Ketersediaan narkotika di satu sisi merupakan obat atau bahan yang bermanfaat di bidang pengobatan atau pelayanan kesehatan dan bermanfaat juga untuk pengembangan ilmu pengetahuan. Tetapi di sisi lain narkotika juga dapat menimbulkan ketergantungan yang sangat merugikan apabila disalahgunakan. ${ }^{5}$ Saat ini penyebarluasan terhadap peredaran dan penyalahgunaan narkotika semakin meluas dan hampir tidak bisa dicegah, mengingat setiap orang dapat mudah memperoleh narkotika dari oknum-oknum yang tidak bertanggung jawab. ${ }^{6}$ Pemakaian narkotika secara terus menerus akan mengakibatkan orang itu bergantung pada

1 Sri Rahayu, Bambang Subiyantoro, Yulia Monita, Dheny Wahyudhi, Penyuluhan Pencegahan Penyalahgunaan Narkotika Di Kalanga Mahasiswa, Jurnal Pengabdian pada Masyarakat, Volume 29, Nomor 4 Agustus - Desember (2014), hlm.1.

2 Siswanto Sunarso, Penegakan Hukum Psikotropika Dalam Kajian Sosiologi Hukum, (Jakarta: Raja Grafindo Persada, 2005), hlm. 6.

3 Siswanto S, Politik Hukum Dalam Undang-undang Narkotika (Undang-Undang Nomor 35 Tahun 2009), (Jakarta: Rineka Cipta, Cet. 1, 2012), hlm.1.

4 Siswanto S, Politik Hukum, hlm. 1.

5 Siswanto S, Politik Hukum, hlm. 1.

6 Siswanto S, Politik Hukum, hlm.2. 
narkotika, secara mental maupun fisik, yang dikenal dengan istilah ketergantungan fisik dan mental. ${ }^{7}$ Seseorang yang sudah pada tingkat ketergantungan narkotika, akan berusaha memperoleh narkotika itu dengan segala macam cara, tanpa memperhatikan norma-norma sosial, norma agama maupun norma hukum yang berlaku, yang pada akhirnya tidak menutup kemungkinan akan melakukan tindakan-tindakan kriminal dan tindakan-tindakan lain yang dapat meresahkan lingkungan keluarga dan masyarakat sekitar.

Penyalahgunaan narkotika maksudnya adalah menggunakan narkotika:
a. Secara terus-menerus/berkesinambungan
b. Sekali-kali (kadang-kadang)
c. Secara berlebihan
d. Tidak menurut petunjuk dokter (non medik). ${ }^{8}$

Penegakan hukum terhadap tindak pidana narkotika telah banyak dilakukan oleh aparat penegak hukum, bukan tak sedikit yang telah melalui putusan pengadilan. ${ }^{9}$ Namun salah satu kendala dalam penegakan pemberantasan penyalahguna narkotika adalah karena terdapat putusan hakim terhadap penyalahguna narkotika yang dirasa kurang tepat, yang semestinya terhadap penyalahguna narkotika tersebut dijatuhi dengan tindakan rehabilitasi, sehingga penyalahguna dapat melepaskan diri dari ketergantungan narkotika itu sendiri akan tetapi terhadap penyalahguna tersebut dijatuhi dengan pidana penjara tanpa direhabilitasi. Hal ini berimplikasi kepada penegakan pemberantasan penyalahgunaan narkotika itu sendiri, salah satunya terhadap pelaku yang menggunakan narkotika atau penyalahguna narkotika, karena kekurang tepatan penjatuhan pidana yang dijatuhkan oleh hakim terhadap penyalahguna narkotika tersebut. Meskipun dalam praktek peradilan, konsekuensi logis dari perumusan normatif undang-undang narkotika baik terhadap pengedar dan pengguna dijatuhkan pidana. ${ }^{10}$ Agar tindak pidana penyalahguna narkotika tidak terus berkembang dan pelakunya jera untuk mengulangi perbuatannya maka perlu dilaksanakan ketentuan hukum pidana yang sebenar-benarnya dengan melarang tindak pidana narkotika dan diterapkan pidananya atas para pelaku sesuai dengan yang diamanatkan di dalam undang-undang dalam hal ini sebagaimana yang terdapat di dalam Undang-Undang Nomor 35 Tahun 2009 Tentang Narkotika.

Penegak hukum harusnya dilandasi dengan etika dan moral sehingga terjadi sinkronisasi antara sisi keadilan dan juga sisi kepastian hukum. Tidak boleh ada upaya penegakan hukum pidana yang hanya mengedepankan sisi kepastian hukum saja, dengan mengesampingkan sisi keadilannya dan begitu pula sebaliknya.

Salah satu proses penegakan hukum adalah terdapat pada institusi pengadilan. Institusi pengadilan berperan untuk mengadili, dan kemudian memutuskan tentang bersalah atau tidaknya seseorang yang disertai dengan penetapan pertanggung

7 Racham Hermawan, Penyalahgunaan Narkotika Oleh Para Remaja, (Bandung: Eresco, 1987), hlm. 84 .

8 Gatot Supramono, Hukum Narkoba Indonesia, (Jakarta: Djambatan, 2001), hlm. 489.

9 A. W. Widjaja, Remaja dan Penyalahgunaan Narkotika, (Palembang: Amrico, 1985), hlm. 3.

10 Adi Kusno, Kebijakan Kriminal Dalam Penanggulangan Tindak Pidana Narkotika Oleh Anak, (Malang: Umm Press, 2009), hlm. 19. 
jawaban pidananya. Di sini diperlukan keahlian, integritas, damn kecermatan hakim dalam memutuskan suatu perkara.

Keahlian hakim sangat diperlukan dalam penguasaan terhadap sebuah kasus. Hakim harus menguasai aspek-aspek lain dalam penegakan hukum (sosial, ekonomi, politik, budaya) sehingga putusan hakim merupakan sebuah putusan yang mewakili 4 (empat) elemen penting tersebut. Hakim tidak boleh menjatuhkan putusan hanya berdasarkan frasa yang disebutkan oleh undang-undang, karena hakim bukan merupakan corongnya undang-undang. Hakim harus mampu berfikir dan bertindak secara progresif sehingga yang didapatkan adalah sebuah kebenaran substantif.

Penggunaan hukum pidana sebagai sarana penanggulangan penyalahgunaan narkotika pada akhirnya akan bermuara pada persoalan bagaimana hakim dalam menjatuhkan putusan. Dasar pertimbangan hakim dalam menjatuhkan pidana akan sangat menetukan apakah putusan seorang hakim dianggap adil atau menentukan apakah putusannya dapt dipertanggung jawabkan atau tidak. ${ }^{11}$

Penerapan pidana yang dilakukan terhadap pelaku tindak pidana narkotika salah satunya terhadap penyalahguna narkotika tentunya tidak terlepas dari etika tentang hukuman legal yaitu:

1. Hak moral untuk menghukum seseorang didasarkan semata-mata atas kenyataan bahwa ia telah terbukti melakukan suatu kesalahan atau kejahatan.

2. Kewajiban moral untuk menghukum secara eksklusif kokoh di atas landasan yang sama.

3. Demi keadilan retributive maka hukuman harus seimbang dengan bobot kesalahan yang telah dilakukan.

4. Dasar moral pemberian hukuman ialah hukuman merupakan "pemutihan" terhadap kesalahan dan "reformasi" terhadap hukum yang dilawan, hukuman merupakan pola "hak" dari pelaku kejahatan.

5. Konsekuensi hukuman sebagai pencegahan agar di masa yang akan dating kejahatan terhukum tak akan terulang lagi.

6. Hukuman itu memberikan kepuasan baik kepada si korban maupun kepada orang lain. ${ }^{2}$

Di wilayah hukum Pengadilan Negeri Jambi terdapat beberapa putusan terhadap pelaku tindak pidana narkotika yang menggunakan narkotika yang melanggar Pasal 127 Undang-Undang Nomor 35 Tahun 2009 tentang Narkotika. Pada Pasal 127 Undang-Undang Nomor 35 Tahun 2009 menentukan bahwa:

(1) Setiap penyalahguna:

a. Narkotika Golongan I bagi diri sendiri dipidana dengan pidana penjara paling lama 4 (empat) tahun;

b. Narkotika Golongan II bagi diri sendiri dipidana dengan pidana penjara paling lama 2 (dua) tahun; dan

c. Narkotika Golongan III bagi diri sendiri dipidana dengan pidana penjara paling lama 1 (satu) tahun.

11 Muhammad Rusli, Potret Lembaga Pengadilan Indonesia, (Jakarta: PT. Raja Grafindo Persada, 2006), hlm. 125.

12 Yong Ohoitimur, Teori Etika Tentang hukuman Ilegal, (Jakarta: PT. Gramedia Pustaka Utama, 1997), hlm. 17-18. 
(2) Dalam memutus perkara sebagaimana dimaksud pada ayat (1), hakim wajib memperhatikan ketentuan sebagaimana dimaksud dalam Pasal 54, Pasal 55, dan Pasal 103.

(3) Dalam hal penyalahguna sebagaimana dimaksud pada ayat (1) dapat dibuktikan atau terbukti sebagai korban penyalahgunaan narkotika, penyalahguna tersebut wajib menjalani rehabilitasi medis dan rehabilitasi sosial.

Putusan terhadap pelaku penyalahguna narkotika di wilayah hukum Pengadilan Negeri Jambi pada tahun 2018, misalnya, terdapat beberapa putusan terhadap pelaku yang menggunakan narkotika yang dapat dilihat pada tabel 1.

Berdasarkan tabel di atas, dapat dilihat bahwa pada perkara Nomor: 563/Pid.Sus/2018/PN.JMB dimana dalam perkara tersebut terdakwa yang bernama M. Hafiz Bin Abdul Fatah telah terbukti menggunakan shabu Amphetamine Metamphetamine yang terdaftar dalam narkotika Golongan I (Satu) pada nomor urut 53 dan nomor 61 pada Lampiran Undang-Undang Nomor 35 Tahun 2009 tentang Narkotika. Pada Perkara tersebut M. Hafiz Bin Abdul Fatah telah terbukti melanggar Pasal 127 ayat (1) huruf a Undang-Undang Nomor 35 Tahun 2009 tentang Narkotika. Berdasarkan hal yang dipertimbangkan oleh hakim, terdakwa M. Hafiz Bin Abdul Fatah diputus dengan pidana penjara selama 8 (delapan) bulan 15 (lima belas) hari dan menetapkan agar terdakwa menjalani pengobatan dan/atau perawatan melalui rehabilitasi medis dan rehabilitasi sosial yang dilakukan di panti rehabilitasi narkotika LIDO Bogor selama 2 (dua) bulan yang diperhitungkan dengan masa pidana yang dijatuhkan kepada terdakwa.

Jika mengacu pada tuntutan jaksa yang mana menuntut pelaku dengan pidana penjara selama 10 (sepuluh) bulan tentunya nampak bahwa putusan hakim lebih ringan dari apa yang menjadi tuntutan dari jaksa. Sedangkan pada perkara nomor 587/Pid.Sus/2018/PN.JMB dimana dalam perkara tesebut terdakwa yang bernama Kemas Muhammad Chaerudin Als Chaerul Bin Abdullah Chalik yang sama-sama terbukti telah menggunakan shabu yang mengandung Amphetamine dan Metamphetamine yang terdaftar dalam Narkotika Golongan I (Satu) pada nomor urut 53 dan nomor 61 dalam Lampiran Undang-Undang Nomor 35 Tahun 2009 tentang Narkotika. Namun dalam penjatuhan putusannya terhadap perkara tersebut terdapat perbedaan, hakim memutuskan pidana penjara selama 6 (enam) bulan tanpa ada pemberian tindakan berupa rehabilitasi, sementara jika mengacu pada tuntutan jaksa yang menuntut pelaku Kemas Muhammad Chaerudin Als Chaerul Bin Abdullah Chalik dengan pidana penjara selama 8 (delapan) bulan. Padahal dengan tuntutan yang ringan tersebut hendaknya hakim juga mencantumkan tindakan rehabilitasi medis dan rehabilitasi sosial dalam putusan yang dijatuhkan tersebut. Karena tindakan rehabilitasi tersebut sangat penting untuk diberikan kepada terdakwa dalam rangka penyembuhan dari penyalahguna narkotika tersebut sehingga putusan yang jatuhkan menjadi bermanfaat dan tepat bagi terdakwa. Oleh Karena itu pada tulisan ini akan menganalisis perkara Nomor : 563/Pid.Sus/2018/PN.JMB dengan perkara Nomor : 587/Pid.Sus/2018/PN.JMB.

Jika dipandang secara normatif, pidana penjara yang dijatuhkan kepada terdakwa penyalahguna narkotika tidaklah salah dan juga di pandang sudah tepat, dimana tindakan tersebut mempunyai tujuan untuk memberikan efek jera kepada terdakwa itu sendiri dan juga kepada orang lain ataupun masyarakat sebagai agar tidak melakukan perbuatan yang sama. Akan tetapi, untuk membebaskan terdakwa 
dari penyalahguna narkotika juga diperlukan tindakan rehabilitasi agar terdakwa sembuh secara fisik disamping dijatuhi dengan pidana penjara sebagai efek jera bagi terdakwa. Untuk itu, hakim perlu mempertimbangkan Pasal 54 Jo. Pasal 103 UndangUndang Nomor 35 Tahun 2009 tentang Narkotika. Dimana pada Pasal 54 UndangUndang Nomor 35 Tahun 2009 disebutkan bahwa: "Pencadu narkotika dan korban penyalahgunaan narkotika wajib menjalani rehabilitasi medis dan rehabilitasi sosial". Sementara Pasal 103 Undang-Undang Nomor 35 Tahun 2009 Tentang Narkotika disebutkan bahwa:

(1) Hakim yang memeriksa perkara pecandu narkotika dapat:

a. Memutus untuk memerintahkan yang bersangkutan menjalani pengobatan dan/atau perawatan melalui rehabilitasi jika pecandu narkotika tersebut terbukti bersalah melakukan tindak pidana narkotika; atau

b. Menetapkan untuk memerintahkan yang bersangkutan menjalani pengobatan dan/atau perawatan melalui rehabilitasi jika pecandu narkotika tersebut tidak terbukti bersalah melakukan tindak pidana narkotika.

(2) Masa menjalani pengobatan dan/atau perawatan bagi pecandu narkotika sebagaimana dimaksud pada ayat (1) huruf a diperhitungkan sebagai masa menjalani hukuman.

Tabel 1

Putusan Pelaku Tindak Pidana Penyalahguna Narkotika Di Pengadilan Negeri Jambi

\begin{tabular}{|c|c|c|c|c|c|}
\hline No. & No.perkara & Tuntutan & Putusan & Rehabilitasi & Pidana \\
\hline 1. & $\begin{array}{l}\text { No. } \\
\text { 563/Pid.Sus/2018/PN. } \\
\text { JMB }\end{array}$ & 10 bulan & $\begin{array}{l}8 \text { bulan } \\
15 \text { hari }\end{array}$ & $\checkmark$ & - \\
\hline 2. & $\begin{array}{l}\text { No. } \\
\text { 587/Pid.Sus/2018/PN. } \\
\text { JMB }\end{array}$ & 8 bulan & 6 bulan & - & $\checkmark$ \\
\hline 3. & $\begin{array}{l}\text { No. } \\
\text { 560/Pid.Sus/2018/PN. } \\
\text { JMB }\end{array}$ & 10 bulan & $\begin{array}{l}8 \text { bulan } \\
15 \text { hari }\end{array}$ & - & $\checkmark$ \\
\hline 4. & $\begin{array}{l}\text { No. } \\
\text { 586/Pid.Sus/2018/PN. } \\
\text { JMB }\end{array}$ & 8 bulan & 6 bulan & - & $\checkmark$ \\
\hline 5. & $\begin{array}{l}\text { No. } \\
\text { 163/Pid.Sus/2018/PN. } \\
\text { JMB }\end{array}$ & $\begin{array}{l}1 \text { tahun } 6 \\
\text { bulan }\end{array}$ & 1 tahun & - & $\checkmark$ \\
\hline
\end{tabular}

Sumber data: Direktori Putusan Mahkamah Agung/PN. Jambi 


\section{B. Metode Penelitian}

Metode yang digunakan dalam penelitian ini adalah yuridis normatif. . Penelitian Yuridis Normatif adalah suatu proses untuk menemukan aturan hukum, prinsipprinsip hukum dan doktrin-doktrin hukum. Penelitian hukum normatif dapat dilakukan terutama terhadap bahan hukum primer dan sekunder, sepanjang bahanbahan itu mengandung kaidah-kaidah hukum.

\section{Pembahasan}

\section{Dasar Pertimbangan Hakim Dalam Tindak Pidana Penyalahguna Narkotika}

Dalam hukum pidana, untuk memperoleh suatu putusan yang adil memerlukan proses yang sangat panjang, yaitu melalui proses beracara. Dalam proses tersebut hakikat yang hendak dicapai adalah hendak menemukan kebenaran materil, yang merupakan landasan dalam penjatuhan sanksi pidana demi tercapainya rasa keadilan. Putusan yang adil dapat diperoleh apabila ditangani oleh seorang hakim yang bukan saja mempunyai integritas keilmuan yang tinggi, namun harus didasari pula oleh jiwa akhlakul karimah. Namun perlu pula kita sadari bahwa di dunia itu tidak ada lagi keadilan yang hakiki, melainkan lebih bersifat keadilan yang relatif/nisbi.

Norma juga diartikan sebagai patokan perilaku dalam suatu kelompok masyarakat tertentu yang pada umumnya berupa perintah dan larangan. Untuk dapat menjalankan fungsinya yang demikian itu, tentu saja norma harus mempunyai kekuatan hukum yang bersifat memaksa. Paksaan ini tertuju kepada para anggota masyarakat dengan tujuan untuk mematuhinya. ${ }^{13}$

Hukum sebagai peraturan-peraturan yang bersifat memaksa yang menentukan tingkah laku manusia salam lingkungan masyarakat, yang dibuat oleh badan-badan resmi yang berwajib, pelanggaran mana terhadap peraturan-peraturan tadi berakibat diambilnya tindakan, yaitu dengan hukuman yang tertentu. ${ }^{14}$

Dalam konteks putusan hakim, maka kaidah atau norma hukum memegang peranan sebagai pedoman (leiding) dan instrument pengujian (toetsingrecht) bagi aktivitas manusia atau seseorang yang diatur dalam ruang lingkup peraturan perundang-undangan yang berlaku. Sifat norma hukum merupakan sisi "das sollen" sebuah putusan hakim. Tanpa memperhatikan norma hukum, maka sesungguhnya putusan hakim tersebut bersifat sewenang-wenang.

Pada dasarnya tugas hakim adalah memberi keputusan dalam setiap perkara atau konflik yang dihadapkan kepadanya, menetapkan hal-hal seperti hubungan hukum, nilai hukum dari perilaku serta kedudukan hukum pihak-pihak yang terlibat dalam suatu perkara, sehingga untuk dapat menyelesaikan perselisihan atau konflik secara imparsial berdasarkan hukum yang berlaku, maka hakim harus selalu mandiri dan bebas dari pengaruh pihak manapun, terutama dalam mengambil keputusan. ${ }^{15}$

Putusan hakim adalah bersifat sangat penting, karena di dalamnya terdapat sebuah nilai yang dapat bersentuhan langsung dengan hak-hak asasi manusia. Pada prinsipnya hanya putusan hakim yang mempunyai kekuatan hukum tetap yang dapat dijalankan. Suatu putusan itu dapat dikatakan telah mempunyai kekuatan hukum tetap

13 Satjipto Rahardjo, Ilmu Hukum, (Bandung: PT. Citra Aditya Bakti, Cetakan Ke-V ,2000), hlm. 27.

14 JCT. Simorangkir, Pelajaran Hukum Indonesia, (Jakarta: Gunung Agung, 1995), hlm. 6.

15 Ahmad Rifai, Penemuan Hukum Oleh Hakim Dalam Perspektif Hukum Progresif, (Jakarta: Sinar Grafika, Edisi ke-1, Cet ke 4, 2018), hlm.2. 
apabila dikeluarkan melalui sebuah persidangan yang terbuka dan transparan dan tidak adanya upaya hukum lain ya ng diajukan, selain itu putusan hakim yang berkekuatan hukum tetap adalah putusan hakim yang dituangkan dalam bentuk tulisan dengan disertai berbagai prasyarat sebagaimana yang telah diatur dalam Pasal 197 KUHAP Ayat (1) diantaranya huruf $\mathrm{f}$ (pasal peraturan perundang-undangan yang menjadi dasar pemidanaan atau tindakan dan peraturan perundang-undangan yang menjadi dasar hukum dari putusan, disertai keadaan yang memberatkan dan yang meringankan terdakwa) dan huruf h (pernyataan kesalahan terdakwa, pernyataan telah terpenuhi semua unsur dalam rumusan tindak pidana disertai dengan kualifikasinya dan pemidanaan atau tindakan yang dijatuhkan).

Putusan hakim pada dasarnya adalah hukum (judge-made-law), sebagaimana hukum pada umumnya itu harus ditaati dan mempunyai kekuatan hukum mengikat para pihak yang berperkara. Putusan hakim mengikat para pihak yang bersangkutan, dalam arti bahwa putusan hakim itu harus dianggap benar sampai dibatalkan oleh pengadilan yang lebih tinggi, sekalipun putusannya itu secara materiil tidak benar (res justicate veritate habetur). ${ }^{16}$

Berdasarkan ketentuan di atas maka tugas seorang hakim adalah:

1. Menerima setiap perkara yang diajukan kepadanya.

2. Memeriksa setiap perkara yang diajukan kepadanya.

3. Mengadili serta menyelesaikan perkara yang diajukan kepadanya.

Hakim dalam kedudukannya yang bebas diharuskan untuk tidak memihak (impartial judge). Sebagai hakim yang tidak memihak dalam menjalankan profesi, mengandung makna bahwa hakim harus selalu menjamin pemenuhan perlakuan sesuai dengan hak-hak asasi manusia khususnya bagi terdakwa. Sebelum hakim memutuskan perkara terlebih dahulu ada serangkaian keputusan yang harus dilakukan, yaitu:

1. Keputusan mengenai perkaranya yaitu apakah perbuatan terdakwa telah melakukan perbuatan yang dituduhkan kepadanya;

2. Keputusan mengenai hukumnnya, yaitu apakah perbuatan yang dilakukan terdakwa tersebut bersalah dan dapat dipidana;

3. Keputusan mengenai pidananya apabila terdakwa memang dapat dipidana ${ }^{17}$

Putusan hakim yang adil bukan saja didasarkan atas keyakinan terhadap buktibukti yuridis yang berhasil diungkapkan Jaksa, melainkan perlu didukung pula oleh kemampuan yang tinggi serta kepribadian yang baik yang dimiliki oleh seorang ahkim

Dari posisi kasus yang sudah di uraikan sebelumnya, adapun dasar pertimbangan hakim dalam putusan perkara tindak pidana narkotika Pasal 127 ayat (1) huruf a Undang-Undang Nomor 35 Tahun 2009 di Pengadilan Negeri Jambi (Studi Kasus Nomor: 563/Pid.Sus/2018/PN.JMB dengan Nomor 587/ Pid.Sus/2018/PN.JMB) maka, dapatlah diketahui bahwa dasar-dasar pertimbangan hakim dalam menjatuhkan putusan itu adalah:

\footnotetext{
16 Leden Marpaung, Asas-Teori-Praktik Hukum Pidana, (Jakarta: Sinar Grafika, Cetakan ketiga, 2006), hlm. 251.

17 Sudarto, Kapita Selekta Hukum Pidana, (Bandung: PT.Alumni, 2010), hlm.74.
} 


\section{Pertimbangan Yuridis}

a. Dakwaan Jaksa Penuntut Umum

- Pada kasus Nomor: 563/Pid.Sus/2018/PN.Jmb di dakwakan dengan dakwaan alternatif, dan tuntutan dari jaksa penuntut umum yaitu Pasal 114, Pasal 112 dan Pasal 127 Ayat (1) Undang-Undang Nomor 35 Tahun 2009 Tentang Narkotika.

- $\quad$ Pada kasus Nomor: 587/Pid.Sus/2018/PN-Jmb di dakwakan dengan dakwaan alternatif, dan tuntutan dari jaksa penuntut umum yaitu dalam Pasal 114, Pasal 112 dan Pasal 127 Ayat (1) Undang-Undang Nomor 35 Tahun 2009 Tentang Narkotika.

\section{Fakta di Persidangan}

Fakta-fakta yang terungkap dipersidangan adalah dilihat dari alat-alat bukti yang ada pada saat pemeriksaan dipengadilan, alat-alat bukti. Dalam Pasal 184 KUHAP menyatakan:

(1) Alat bukti yang sah ialah:

1. Keterangan Saksi

2. Keterangan Ahli

3. Surat

4. Petunjuk

5. Keterangan Terdakwa ${ }^{18}$

a. Keterangan Saksi

Dari kedua kasus yang terjadi, para saksi yang berada di TKP memberikan keterangan yang pada intinya membenarkan bahwa telah terjadi tindak pidana penyalahgunaan narkotika.

b. Keterangan Ahli

- $\quad$ Pada kasus Nomor: 563/Pid.Sus/2018/PN.Jmb, Saksi Dr. Victor Eliezer, SpKj adalah dokter yang melakukan perawatan terhadap terdakwa selama menjalani rehabilitasi di Rumah Sakit Jiwa, saksi melakukan asessment terhadap terdakwa M. Hafiz Bin Abdul, berdasarkan hasil Tim Asesmen Terpadu telah disimpulkan bahwa terdakwa dapat menjalani perawatan/pengobatan melalui rehabilitasi medis dilembaga rehabilitasi yang ditunjuk oleh pemerintah setelah putusan hakim, Bahwa sesuai dengan surat rekomendasi rehabilitasi dari kepala BNNP Jambi nomor : R/445/IV/Ka/RH.00.00/2014/BNNP-JBI tanggal 18 April 2018 terdakwa pernah dilakukan pengobatan melalui Rehabiliasi medis di Rumah Sakit Jiwa Provinsi Jambi sejak tanggal 20 April 2018 sampai dengan tanggal 27 Juli 2018, Bahwa Terdakwa pertama kali menggunakan narkotika jenis sejak tahun 2009 hingga tertangkap dan terdakwa menggunakan shabu-shabu dalam satu minggu 3 (tiga) kali.

- Pada kasus Nomor: 587/Pid.Sus/2018/PN-Jmb ia tidak ada menghadirkan saksi ahli kepersidangan.

18 Yulia Monita dan Dheny Wahyudhi, Peranan Dokter Forensik Dalam Pembuktian Perkara Pidana. 
c. Surat

- $\quad$ Surat yang dijadikan alat bukti pada kasus Nomor: 563/Pid.Sus/2018/PN.JMB adalah Hasil Surat Keterangan Pengujian dari Balai POM Jambi Nomor: PM.01.05.881.04.18.1002 tanggal 03 April 2018,

- Sedangkan pada kasus Nomor: 587/Pid.Sus/2018/PN-Jmb adalah Hasil Pemeriksaan Badan POM Jambi Nomor: PM.01.05.881.03.18.773 tertanggal 13 Maret 2018.

d. Petunjuk

Yaitu persesuaian antara semua alat-alat bukti, yaitu keterangan saksi yang satu dengan saksi yang lain.

e. Keterangan Terdakwa

- Dalam kasus Nomor: 563/Pid.Sus/2018/PN.JMB terdapat keterangan dari Victor Eliezer, yang dari keterangannya dapat meringankannya dan terdakwa membenanrkan semua keterangan saksi yang diajukan dipersidangan. Sementara itu

- $\quad$ pada kasus Nomor: 587/Pid.Sus/2018/PN-Jmb terdakwa tidak mengajukan saksi yang dapat meringankannya (ade charge) dan membenarkan semua keterangan saksi yang diajukan ke persidangan.

Kedua kasus ini dikenakan Pasal 127 ayat (1) Undang-Undang Nomor 35 Tahun 2009 tentang Narkotika.

masing-masing pidana:

- kasus Nomor: 563/Pid.Sus/2018/PN.JMB dengan pidana penjara 8 (delapann) bulan 10 (sepuluh) hari dan menjalani rehabilitasi medis dan sosial.

- $\quad$ kasus Nomor: 587/Pid.Sus/2018/PN-Jmb dengan pidana penjara 6 (enam) bulan.

\section{Pertimbangan Sosiologis}

Pada kasus Nomor: 563/Pid.Sus/2018/PN.JMB, Hal-hal yang memberatkan dan meringankan terdakwa adalah:

a. Keadaan yang memberatkan:

- $\quad$ Perbuatan terdakwa meresahkan masyarakat.

- Terdakwa tidak mendukung pogram pemerintah untuk memberantas penyalahgunaan Narkotika.

b. Keadaan yang meringankan:

- Terdakwa menyesali perrbuatannya dan berkeinginan untuk sembuh dari ketergantungan Narkotika.

- Terdakwa memilik tanggungan keluarga.

Pada kasus Nomor: 587/Pid.Sus/2018/PN-Jmb, Hal-hal yang memberatkan dan meringankan terdakwa adalah:

a. Hal-hal yang memberatkan:

- $\quad$ Perbuatan Terdakwa menghambat program pemerintah dalam memberantas tindak pidana narkotika.

- Perbuatan Terdakwa meresahkan masyarakat.

b. Hal-hal yang meringankan:

- Terdakwa bersikap sopan di persidangan.

- Terdakwa mengakui dan menyesali perbuatannya serta berjanji tidak akan mengulangi lagi. 
Hakim menjatuhkan putusan pidana selama 8 (delapan) bulan dan 15 (lima belas) hari dan menjalani rehabilitasi pada kasus Nomor: 563/Pid.Sus/2018/PN.Jmb karena terdakwa merupakan korban penyalahguna narkotika yang sudah kecanduan dimana hal ini diperkuat dengan keterangan saksi yang dihadirkan di persidangan yaitu Dr. Victor Eliezer, SpKj. Bahwa saksi adalah dokter yang pernah melakukan perawatan terhadap terdakwa selama menjalani rehabilitasi di Rumah Sakit Jiwa, terdakwa sudah menggunakan Narkotika sejak tahun 2009 hingga tertangkap, sehingga menurut saksi, upaya untuk menghilangkan ketergantungan menggunakan narkotika adalah dengan melakukan rehabilitasi.

Sementara pada kasus Nomor: 587/Pid.Sus/2018/PN-Jmb terdakwa merupakan pelaku penyalahguna narkotika, tentu jika kedudukan kedua terdakwa tersebut berbeda yang mana satunya sebagai korban dan yang satunya sebagai pelaku. Kemudian tidak ada keterangan dari dokter yang menyatakan ketergantungan, atas dasar ini lah hakim menjatuhkan pidana penjara selama 6 (enam) bulan terhadap terdakwa. Jika kita kaji mengenai berat ringannya putusan hakim yang dijatuhkan terhadap kedua kasus tersebut, Dalam tulisan ini putusan hakim pada kasus Nomor: 587/Pid.Sus/2018/PN.Jmb lebih ringan dari putusan hakim pada kasus Nomor: 563/Pid.Sus/2018/PN Jmb.

Adapun selanjutnya sebagai tolak ukur tindakan yang dapat dikenakan bagi seorang pecandu penyalahguna narkotika sebagaimana dimaksud dalam Pasal 127. Pasal 103 UU Nomor 35 Tahun 2009 adalah Surat Edaran Mahkamah Agung (SEMA) Republik Indonesia Nomor 4 Tahun 2010.

Surat Edaran Mahkamah Agung Republik Indonesia diatas dapat juga dijadikan tolak ukur bagi seorang penyalahguna yang diancam pidana penjara sebagaimana dimaksud dalam Pasal 127 Ayat (1) Undang-undang Nomor 35 Tahun 2009. Karena secara logika, antara pecandu dengan penyalahguna adalah sama-sama menyalahgunakan narkotika, hanya saja untuk membedakannya perlu terlebih dahulu dilakukan asesmen atau pembuktian bagi terdakwa hingga dapat diketahui oleh Hakim apakah terdakwa tersebut adalah seorang Pecandu yang memiliki ketergantungan tinggi terhadap narkotika ataukah hanyalah penyalahguna yang bukan seorang pecandu. Berdasarkan SEMA Nomor 4 Tahun 2010 tersebutlah yang memperkuat keyakinan hakim untuk tidak menjatuhkan putusan berupa tindakan rehabilitasi pada kasus Nomor: 587/Pid.Sus/2018/PN-Jmb, karena terdakwa tidak mengalami ketergantungan narkotika dan terdakwa menggunakan narkotika jenis shabu pemakaian satu hari yang tidak mencapai 1 gram. Ini berati tidak memenuhi butir 2 huruf a adalah Surat Edaran Mahkamah Agung (SEMA) Republik Indonesia Nomor 4 Tahun 2010 tentang Penempatan Penyalahgunaan, Korban Penyalahgunaan dan Pecandu Narkotika ke dalam Lembaga Rehabilitasi Medis dan Rehabilitasi Sosial. Akan tetapi meskipun demikian hakim dalam menjatuhkan pidana bukan saja hanya mempertimbangkan berat ringannya perbuatan yang dilakukan oleh terdakwa, tetapi juga harus memperhatikan pengaruh tindak pidana tersebut terhadap masyarakat serta manfaat pidana itu sendiri bagi si terdakwa.

Putusan hakim akan berakibat fatal apabila dihubungkan dengan kepercayaan masyarakat pencari kedailan. Sebab, hal ini bila tidak segera diatasi atau paling tidak diminimalisir, dapat berdampak luas, yaitu muncul ketidak percayaan terhadap lembaga peradilan, kemudian ketidakpuasan masyarakat karena ketidakadilan hakim dalam menjatuhkan putusan pidana, sehingga muncul ketidakpercayaan masyarakat luas. 


\section{Simpulan}

Berdasarkan hasil pembahasan tersebut di atas, penulis dapat menarik kesimpulan bahwa Majelis Hakim dalam menjatuhkan hukuman kepada terdakwa pada kasus Nomor: 563/Pid.Sus/2018/PN.Jmb dengan kasus Nomor: 587/Pid.Sus/2018/PN.Jmb tentang Narkotika tersebut sudah tepat. Karena Dasar Pertimbangan Hakim menjatuhkan putusan tersebut yaitu mempertimbangkan hal-hal pada pertimbangan yuridis, fakta di persidangan dan pertimbangan sosiologis. Pertimbangan hakim yang bersifat yuridis yaitu dilihat dari dakwaan, tuntutan jaksa penuntut umum dan unsur delik pada Pasal 127 ayat (1) Undang-Undang Nomor 35 Tahun 2009 tentang Narkotika, dan pertimbangan fakta dipersidangannya ialah dengan melihat alat-alat bukti yang dihadirkan dipersidangan, alat-alat bukti tersebut ialah keterangan saksisaksi, keterangan ahli yaitu keterangan dari Victor Eliezer, surat yaitu surat rekomendasi dari Badan Narkotika Nasional (BNN), petunjuk dan keterangan terdakwa. Pertimbangan hakim yang bersifat sosiologis yaitu hal-hal yang memberatkan dan hal-hal yang meringankan terdakwa yang bersifat yuridis dan sosiologis.

Pertimbangan Hakim pada kasus Nomor: 587/Pid.Sus/2018/PN Jmb hakim menjatuhkan pidana penjara tersebut sudah tepat karena terdakwa merupakan pelaku bukan korban penyalahguna narkotika dan tidak adanya keterangan yang menyatakan bahwa pelaku mengalami ketergantungan narkotika, serta pelaku menggunakan narkotika jenis shabu pemakaian satu hari yang tidak mencapai 1 gram. Ini berarti tidak memenuhi butir 2 huruf a Surat Edaran Mahkamah Agung (SEMA) Republik Indonesia Nomor 4 Tahun 2010 tentang Penempatan Penyalahgunaan, Korban Penyalahgunaan dan Pecandu Narkotika ke dalam Lembaga Rehabilitasi Medis dan Rehabilitasi Sosial.

\section{DAFTAR PUSTAKA}

\section{Dokumen Hukum}

Jambi, Putusan Nomor 563/Pid.Sus/2018/PN.Jmb, Putusan Nomor: 587/Pid.Sus/2018/PN.Jmb

Republik Indonesia, Undang-Undang Nomor 35 Tahun 2009 Tentang Narkotika.

\section{Buku}

Adi Kusno. Kebijakan Kriminal Dalam Penanggulangan Tindak Pidana Narkotika Oleh Anak, Malang: Umm Press, 2009.

Ahmad Rifai. Penemuan Hukum Oleh Hakim Dalam Persfektif Hukum Progresif, Jakarta: Sinar Grafika, Edisi ke-1,Cet.4, Jakarta, 2018.

A. W. Widjaja. Remaja dan Penyalahgunaan Narkotika, Palembang: Amrico, 1985.

Gatot Supramono. Hukum Narkoba Indonesia, Jakarta: Djambatan, 2001.

JCT. Simorangkir. Pelajaran Hukum Indonesia, Jakarta: Gunung Agung, 1995.

Leden Marpaung. Asas-Teori-Praktik Hukum Pidana, Jakarta: Sinar Grafika, Cetakan Ketiga, 2006. 
Muhammad Rusli. Potret Lembaga Pengadilan Indonesia, Jakarta: PT. Raja Grafindo Persada, 2006.

Racham Hermawan. Penyalahgunaan Narkotika Oleh Para Remaja, Bandung: Eresco, 1987.

Satjipto Rahardjo. Ilmu Hukum, Bandung: PT. Citra Aditya Bakti, Cetakan Ke-V, 2000.

Siswanto Sunarso. Penegakan Hukum Psikotropika Dalam Kajian Sosiologi Hukum, Jakarta: Raja Grafindo Persada, 2005.

Siswanto S. Politik Hukum Dalam Undang-undang Narkotika (Undang-Undang Nomor 35 Tahun 2009), Jakarta: Rineka Cipta, Cet. 1,2012.

Sudarto. Kapita Selekta Hukum Pidana, Bandung: PT.Alumni, 2010.

Yong Ohoitimur. Teori Etika Tentang hukuman Ilegal, Jakarta: PT. Gramedia Pustaka Utama, 1997.,

Jurnal

Sri Rahayu, Bambang Subiyantoro. Yulia Monita, Dheny Wahyudhi, Penyuluhan Pencegahan Penyalahgunaan Narkotika Di Kalanga Mahasiswa, Jurnal Pengabdian pada Masyarakat, Vol. 29, No. 4 Agustus - Desember 2014.

Yulia Monita dan Dheny Wahyudhi. Peranan Dokter Forensik Dalam Pembuktian Perkara Pidana. Jurnal Ilmu Hukum, Volume 6, Nomor 7, 2013. 